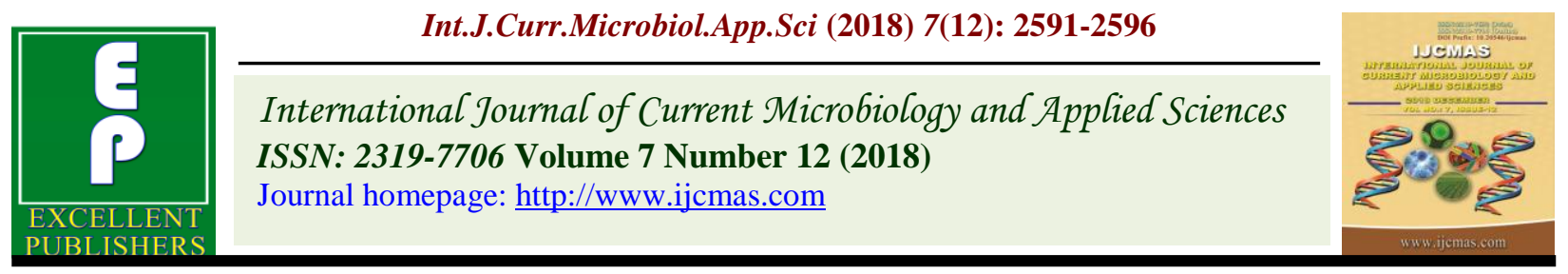

Original Research Article

https://doi.org/10.20546/ijcmas.2018.712.294

\title{
Effect of Seed Scarification Treatments on Ber (Ziziphus rotundifolia Lamk.) Seedling Biomass
}

\author{
Vikas Sheoran $^{1}$, Mukesh Kumar ${ }^{2 *}$, Vijay, Sushil Sharma ${ }^{2}$ and D.V. Pathak ${ }^{2}$ \\ ${ }^{1}$ Department of Horticulture, CCS Haryana Agricultural University, Hisar, Haryana, India \\ ${ }^{2}$ CCS HAU, Regional Research Station, Bawal (Rewari), India \\ *Corresponding author:
}

Ke ywords

Gibberellic acid, Fresh weight, Root and shoot biomass, Scarification, Ziziphus rotundifolia (wild ber).

\section{Article Info}

Accepted:

17 November 2018

Available Online:

10 December 2018

\section{A B S T R A C T}

This study was conducted in the nursery block of experimental orchard, Department of Horticulture, CCS HAU, Hisar to find out suitable scarification treatment for seedling biomass of ber. There were 14 treatments of seed scarification i.e. sulphuric acid soaking for $5 \mathrm{~min}$ and $10 \mathrm{~min}$, gibberellic acid soaking@ 250 ppm for 12 and 24 hours, gibberellic acid soaking@ 500 ppm for 12 and 24 hours, potassium nitrate soaking @ 1 percent for 12 and 24 hours, potassium nitrate soaking @ 2 percent for 12 and 24 hours, water soaking for 24 and 48 hours, mechanical scarification and control. The performance of scarification treatments under nursery condition was recorded best in gibberellic acid soaking @ 250 ppm for 24 hours, it resulted into highest fresh weight of roots $(8.52 \mathrm{~g})$, fresh weight of shoots $(24.30 \mathrm{~g})$, roots biomass $(5.16 \mathrm{~g})$ and shoots biomass $(11.44 \mathrm{~g})$, however, it was recorded lowest in control.

\section{Introduction}

The Ziziphus comprising of about 40 species distributed throughout the tropical and subtropical regions of the world. The wild species of ber, (Ziziphus rotundifolia Lamk.) is used as rootstock for commercially grown ber orchard. Rootstocks play an important role in growing of fruit plants in problematic soil. Besides being rich in nutritive value, it is regular and prolific bearer. It can be grown in grown easily in a barren land and adverse climatic conditions, where most of the other fruits cannot be grown successfully (Kumar et al., 2017). Ber crop exhibits xerophytic characters with wider adaptability to adverse soils and climatic conditions. Being a least care requiring crop, it is suitable to rehabilitate the extensive resource for poor man's health in poor man's areas and poor soils.

Most of the rootstocks are grown by seeds/ stones for vegetative propagation but due to hard seed coat their germination is a problem. The removal of hard seed coat either by mechanical or chemical means can promote the germination. The dormancy in seeds might be due to hard seed coat which resulted in impermeability to water and gases, physiological immaturity of embryo, 
deficiency/ excess of some endogenous growth promoters/inhibitors. Different methods like water soaking, scarification and chemical treatments are used for breaking dormancy to improve seed germination. Soaking duration varies from overnight to 3 or 4 days depending on the nature of seed coat while, scarification is the process of removing the hard seed coat by any means to accelerate the water absorption and improve gaseous exchange for hastening the process of germination. This can be achieved by mechanical scarification or by acid scarification. Dormancy of the hard seed can be broken by gibberllic acid treatment, scarification, stratification, chilling treatment, hot water treatment, soaking in water and acid treatment depending on the kind of dormancy (Kher and Nataraj, 2015). The scarification of seeds not only improves the germination but accelerate early germination, seedling growth and biomass production.

\section{Materials and Methods}

The field experiment was conducted in fruit plants nursery, Department of Horticulture; which is situated at $215.2 \mathrm{~m}$ above mean sea level with coordinates of $29^{\circ} 10^{\prime} \mathrm{N}$ latitude and $75^{\circ} \quad 46^{\prime}$ E longitudes, CCS Haryana Agricultural University, Hisar. Ripe fruits of Z. rotundifolia were harvested in the month of March from experimental orchard. These fruits were kept in water for 2-3 days to remove peel and adhered pulp portion from the stone. The extracted seed/stone were cleaned thoroughly, dried in shade and stored at room temperature. Scarification treatments viz., sulphuric acid soaking, gibberellic acid soaking, potassium nitrate soaking, water soaking, mechanical scarification were compared with control (not scarified seeds) in different concentrations in the month of May. These scarified seeds were sown in the polybags.

Five randomly selected seedlings were taken for fresh weight of root shoot 60,90 and 120 days after sowing. The roots and shoots were separated as below ground and above ground portion. The roots were dipped in water tub to remove the adhered soil particles. Then roots were kept in shade to drain the excess water thereafter fresh weight was measured with the help of digital electric balance and measured in grams.

After taking the fresh weight the roots and shoots were dried in oven at $60 \pm 2^{\circ} \mathrm{C}$ temperature till the constant weight achieved for root and shoot biomass. The data was analyzed by using the completely randomized block design by applying the technique of analysis of variance by Fisher (1958). The data presented in this paper are the mean values of different parameters and the significance level is compared with the critical difference.

\section{Results and Discussion}

The fresh weight of shoot increased in all the chemical treatments as compared to control at 60, 90 and 120 DAS. Highest fresh shoot weight i.e. $4.01 \mathrm{~g}, 10.21 \mathrm{~g}$ and $24.30 \mathrm{~g}$ was recorded at 60,90 and 120 DAS, respectively, in seed treatment with gibberellic acid soaking @ 250 ppm for 24 hours (Table 1). Lowest fresh weight of shoot was recorded in control as $2.51 \mathrm{~g}, 5.51 \mathrm{~g}$ and $11.12 \mathrm{~g}$ at 60,90 and 120 DAS, respectively; however, at 60 DAS and 90 DAS lowest value of fresh weight of shoot (control) was found at par with mechanical scarification and water soaking treatments for 24 and 48 hours. Seedling biomass was increased due to overall growth of seedlings and increased rate of photosynthesis and translocation of photosynthates within seedlings and thus resulted into higher dry weight/ biomass per seedling. Similar trends was also observed by Chaudhary and Chakrawar, 1981 (kagzi lime); Sasikala and Srimathi, 2006 (papaya). This might be due to better overall performance of growth parameters which finally, increased the dry 
weight/ biomass. Results are in confirmation with Patel et al., (2016) in custard apple. Fresh root weight at 120 DAS showed significant results of the scarification treatments.

Table.1 Effect of seed scarification treatments on fresh weight of shoot of Ziziphus rotundifolia grown in poly bags

\begin{tabular}{|l|l|l|l|}
\hline \multirow{2}{*}{ Treatments } & \multicolumn{3}{l}{ Fresh weight of shoot (g) } \\
\cline { 2 - 4 } & DAS & \multicolumn{2}{l|}{} \\
\cline { 2 - 4 } & 60 & 90 & 120 \\
\hline Control & 2.51 & 5.51 & 11.12 \\
\hline Sulphuric acid soaking for 5 min & 2.77 & 6.12 & 14.57 \\
\hline Sulphuric acid soaking for 10 min & 2.67 & 6.01 & 14.07 \\
\hline Gibberellic acid soaking @ 250 ppm for 12 hrs & 3.52 & 8.21 & 22.15 \\
\hline Gibberellic acid soaking @ 500 ppm for 12 hrs & 3.21 & 7.82 & 21.15 \\
\hline Gibberellic acid soaking @ 250 ppm for 24 hrs & 4.01 & 10.21 & 24.30 \\
\hline Gibberellic acid soaking @ 500 ppm for 24 hrs & 3.71 & 9.13 & 22.17 \\
\hline Potassium nitrate soaking @ 1.0\% for 12 hrs & 2.88 & 6.31 & 15.16 \\
\hline Potassium nitrate soaking @ 2.0\% for 12 hrs & 2.84 & 6.26 & 15.00 \\
\hline Potassium nitrate soaking @ 1.0\% for 24 hrs & 3.02 & 7.01 & 15.57 \\
\hline Potassium nitrate soaking @ 2.0\% for 24 hrs & 3.00 & 6.67 & 15.23 \\
\hline Water soaking for 24 hrs & 2.59 & 5.73 & 13.80 \\
\hline Water soaking for 48 hrs & 2.62 & 5.78 & 14.05 \\
\hline Mechanical scarification & 2.59 & 5.67 & 12.86 \\
\hline C.D. at 5\% & 0.15 & 0.38 & 0.95 \\
\hline
\end{tabular}

Table.2 Effect of seed scarification treatments on fresh weight of root of Ziziphus rotundifolia grown in poly bags

\begin{tabular}{|l|c|c|c|}
\hline \multirow{2}{*}{ Treatments } & \multicolumn{3}{|c|}{ Fresh weight of root (g) } \\
\cline { 2 - 4 } & 60 & 90 & 120 \\
\hline Control & 0.44 & 1.96 & 3.91 \\
\hline Sulphuric acid soaking for 5 min & 0.49 & 2.14 & 5.28 \\
\hline Sulphuric acid soaking for 10 min & 0.46 & 2.12 & 5.08 \\
\hline Gibberellic acid soaking @ 250 ppm for 12 hrs & 0.69 & 2.89 & 7.61 \\
\hline Gibberellic acid soaking @ 500 ppm for 12 hrs & 0.59 & 2.71 & 7.30 \\
\hline Gibberellic acid soaking @ 250 ppm for 24 hrs & 0.72 & 3.61 & 8.52 \\
\hline Gibberellic acid soaking @ 500 ppm for 24 hrs & 0.70 & 3.28 & 8.45 \\
\hline Potassium nitrate soaking @ 1.0\% for 12 hrs & 0.51 & 2.22 & 5.43 \\
\hline Potassium nitrate soaking @ 2.0\% for 12 hrs & 0.49 & 2.19 & 5.29 \\
\hline Potassium nitrate soaking @ 1.0\% for 24 hrs & 0.54 & 2.47 & 5.51 \\
\hline Potassium nitrate soaking @ 2.0\% for 24 hrs & 0.52 & 2.36 & 5.50 \\
\hline Water soaking for 24 hrs & 0.44 & 2.00 & 4.85 \\
\hline Water soaking for 48 hrs & 0.46 & 2.06 & 4.93 \\
\hline Mechanical scarification & 0.44 & 1.99 & 4.49 \\
\hline C.D. at 5\% & 0.03 & 0.13 & 0.37 \\
\hline
\end{tabular}


Table.3 Effect of seed scarification treatments on shoot biomass of Ziziphus rotundifolia grown in poly bags

\begin{tabular}{|l|c|c|c|}
\hline \multirow{2}{*}{ reatments } & \multicolumn{3}{|c|}{ Shoot biomass (g) } \\
\cline { 2 - 4 } & \multicolumn{3}{|c|}{ DAS } \\
\hline Control & 0.68 & $\mathbf{9 0}$ & $\mathbf{1 2 0}$ \\
\hline Sulphuric acid soaking for 5 min & 0.82 & 2.35 & 4.01 \\
\hline Sulphuric acid soaking for 10 min & 0.80 & 2.74 & 5.58 \\
\hline Gibberellic acid soaking @ 250 ppm for 12 hrs & 1.27 & 4.52 & 8.54 \\
\hline Gibberellic acid soaking @ 500 ppm for 12 hrs & 1.12 & 4.09 & 7.76 \\
\hline Gibberellic acid soaking @ 250 ppm for 24 hrs & 1.48 & 5.39 & 11.44 \\
\hline Gibberellic acid soaking @ 500 ppm for 24 hrs & 1.38 & 4.79 & 8.82 \\
\hline Potassium nitrate soaking @ 1.0\% for 12 hrs & 1.03 & 3.13 & 6.33 \\
\hline Potassium nitrate soaking @ 2.0\% for 12 hrs & 0.96 & 2.91 & 5.84 \\
\hline Potassium nitrate soaking @ 1.0\% for 24 hrs & 1.10 & 3.87 & 7.57 \\
\hline Potassium nitrate soaking @ 2.0\% for 24 hrs & 1.04 & 3.50 & 7.23 \\
\hline Water soaking for 24 hrs & 0.73 & 2.59 & 5.08 \\
\hline Water soaking for 48 hrs & 0.76 & 2.71 & 5.21 \\
\hline Mechanical scarification & 0.69 & 2.54 & 4.83 \\
\hline C.D. at 5\% & 0.05 & 0.10 & 0.19 \\
\hline
\end{tabular}

Table.4 Effect of seed scarification treatments on root biomass of Ziziphus rotundifolia grown in poly bags

\begin{tabular}{|l|c|c|c|}
\hline \multirow{2}{*}{ Treatments } & \multicolumn{3}{|c|}{ Root biomass (g) } \\
\cline { 2 - 4 } & $\mathbf{6 0}$ & $\mathbf{9 0}$ & $\mathbf{1 2 0}$ \\
\hline Control & 0.13 & 0.90 & 2.52 \\
\hline Sulphuric acid soaking for 5 min & 0.17 & 1.21 & 3.51 \\
\hline Sulphuric acid soaking for 10 min & 0.14 & 1.39 & 3.19 \\
\hline Gibberellic acid soaking @ 250 ppm for 12 hrs & 0.19 & 1.78 & 5.04 \\
\hline Gibberellic acid soaking @ 500 ppm for 12 hrs & 0.19 & 1.64 & 4.08 \\
\hline Gibberellic acid soaking @ 250 ppm for 24 hrs & 0.21 & 2.36 & 5.16 \\
\hline Gibberellic acid soaking @ 500 ppm for 24 hrs & 0.20 & 2.18 & 4.78 \\
\hline Potassium nitrate soaking @ 1.0\% for 12 hrs & 0.18 & 1.41 & 2.80 \\
\hline Potassium nitrate soaking @ 2.0\% for 12 hrs & 0.17 & 1.43 & 3.51 \\
\hline Potassium nitrate soaking @ 1.0\% for 24 hrs & 0.19 & 1.51 & 3.15 \\
\hline Potassium nitrate soaking @ 2.0\% for 24 hrs & 0.18 & 1.47 & 3.41 \\
\hline Water soaking for 24 hrs & 0.12 & 1.02 & 3.02 \\
\hline Water soaking for 48 hrs & 0.13 & 1.12 & 2.68 \\
\hline Mechanical scarification & 0.12 & 1.08 & 2.57 \\
\hline C.D. at 5\% & NS & 0.29 & 0.50 \\
\hline
\end{tabular}


However, at 60 DAS fresh root weight with mechanical scarification and water soaking for 24 hours were at par with control. However, 90 DAS mechanical scarification and water soaking for 24 hours were at par with control. Highest fresh root weight of ber seedling was recorded as $0.72 \mathrm{~g}, 3.61 \mathrm{~g}$ and $8.52 \mathrm{~g}$ at 60,90 and 120 DAS with gibberellic acid soaking @ 250 ppm for 24 hours, respectively (Table 2). These values at 60 DAS $(0.70 \mathrm{~g})$ and 120 DAS $(8.45 \mathrm{~g})$ were at par with gibberellic acid soaking @500 ppm for 24 hours. The minimum fresh root weight of ber seedling after 60, 90 and 120 DAS was observed in control i.e. $0.44 \mathrm{~g}, \quad 1.96 \mathrm{~g}$ and $3.91 \mathrm{~g}$, respectively, it was found at par with water soaking for 24 hours and mechanically scarification treatments at 60 and 90 DAS, and water soaking for 48 hours at 90 DAS. The increase in fresh weight of root might be due to better growth of plants under gibberellic acid treatment and the root /shoot ratio in most of the plants remain equal.

The shoot biomass was significantly increased by different scarification treatments as compared to control, except biomass at 60 DAS in mechanical scarification and water soaking for 24 hours treatments. Highest shoot biomass was recorded as $1.48 \mathrm{~g}, 5.39 \mathrm{~g}$ and $11.44 \mathrm{~g}$ with gibberellic acid soaking @ 250 ppm for 24 hours at 60, 90 and 120 DAS, respectively (Table 3). However, lowest shoot biomass was recorded as $0.68 \mathrm{~g}, 2.35 \mathrm{~g}$ and $4.01 \mathrm{~g}$ at 60, 90 and 120 DAS, respectively, in the control, which was at par to the values at 60 DAS with mechanical scarification and water soaking for 24 hours.

The root biomass at 60 DAS was observed as non-significant when compared with control. The root biomass at 90 and 120 DAS was enhanced significantly with scarification treatments, except mechanical scarification and water soaking for 24 hours and 48 hours, which was at par with the control. Maximum root biomass of ber seedling after 90 and 120 DAS was recorded with gibberellic acid soaking @ 250 ppm for 24 hours i.e. 2.36g and 5.16g, respectively, which was statistically at par with gibberellic acid soaking @500 ppm for 24 hours and gibbberllic acid soaking @250 ppm for 12 hours treatments at 90 and 120 DAS (Table 4). The minimum root biomass at 90 and 120 DAS was observed in control i.e. $0.90 \mathrm{~g}$ and $2.52 \mathrm{~g}$, respectively, these scarification treatments were at par with other scarification treatments, except mechanical scarification and water soaking for 24 hours and 48 hours. Higher roots biomass may be due to accumulation of more food material as well as higher weight under this treatment.

Fresh weight of shoot of ber seedling was significantly enhanced by gibberellic acid treatments in comparison to other treatments. The maximum fresh weight of shoot of ber seedling after 60, 90 and 120 DAS was recorded with gibberellic acid soaking @250 ppm for 24 hours i.e. 4.01g, 10.21g and $24.30 \mathrm{~g}$, respectively and biomass $1.48 \mathrm{~g}, 5.39$ $\mathrm{g}$ and $11.44 \mathrm{~g}$, respectively. Similarly, fresh weight and biomass was also recorded higher with gibberellic acid soaking @250 ppm for 24 hours.

\section{References}

Chaudhary, B.K. and Chakrawar, V.R. (1981). Effect of seed treatment with certain growth regulators on the shoot and root development of Kagzi lime (Citrus aurantifolia Swingle). Journal of Maharashtra Agricultural University, 6(1): 19-21.

Fisher, R.A. (1958). Statistical methods for research workers, Ed. 10. Oliver and Boyd. Edenburg, London, pp. 224.

Kher, M.M. and Nataraj, M. (2015). Effect of sulphuric acid treatment on breaking of seed dormancy and germination of 
Indian Doum Palm, Hyphaene dichotoma, a threatened and endemic palm. Environment and Experimental Biology, 13: 99-101.

Kumar, M., Singh S., Godara, R.K., Singh D. and Pathak, D.V. (2017). Effect of predrying treatments, drying methods and storage of dehydrated mature and ripe fruits ber fruits cv. Kaithali and Umran on non-enzymatic browning. Journal of Agriculture Technology, 4(2): 23-30.
Patel, D.D., Gaikwad, S.S. and Patel, K. (2016). Effect of seed priming treatments on germination and seedling vigour of custard apple (Annona squamosa). Current Horticulture, 4(2): 21-24.

Sasikala, S. and Srimathi, P. (2006). Influence of storage period and $\mathrm{GA}_{3}$ on germination and vigour of papaya seed. Progressive Horticulture, 38(2): 19598.

\section{How to cite this article:}

Vikas Sheoran, Mukesh Kumar, Vijay, Sushil Sharma and Pathak, D.V. 2018. Effect of Seed Scarification Treatments on Ber (Ziziphus rotundifolia Lamk.) Seedling Biomass. Int.J.Curr.Microbiol.App.Sci. 7(12): 2591-2596. doi: https://doi.org/10.20546/ijcmas.2018.712.294 